PHARMACON- PROGRAM STUDI FARMASI, FMIPA, UNIVERSITAS SAM RATULANGI,

Volume 8 Nomor 3 Agustus 2019

\title{
AKTIVITAS ANTIMIKROBA DARI EKSTRAK DAN FRAKSI ORGANISME LAUT SPONS Stylissa carteri YANG DIKOLEKSI DARI PERAIRAN SELAT LEMBEH KOTA BITUNG
}

\author{
Cavieta Ciendy Ashtita Watupongoh ${ }^{1)}$, Defny S. Wewengkang ${ }^{1)}$, Henki Rotinsulu ${ }^{1)}$ \\ ${ }^{1)}$ Program Studi Farmasi FMIPA UNSRAT Manado, 95115
}

\begin{abstract}
Sponge is a multi-cell marine biota whose tissue and organ functions are very simple. Sponges have considerable potentially in producing active compounds that can be used in the pharmaceutical world. This study aimed to determine the presence of antimicrobial activity from extracts and fractions of the Stylissa carteri Sponge on against the microbes of Staphylococcus aureus, Escherichia coli, and Candida albicans. The extraction process was carried out by maceration using ethanol solvent, and fractionation was carried out using methanol, n-hexane and chloroform solvents. Antimicrobial activity was carried out by disk diffusion agar method. The results showed that the crude ethanol extracts and methanol fractions of the Stylissa carteri sponge actively inhibited the growth of Staphylococcus aureus, Escherichia coli, and Candida albicans microbes.
\end{abstract}

Keywords: Stylissa carteri, antimicrobial, Staphylococcus aureus, Escherichia coli, Candida albicans.

\begin{abstract}
ABSTRAK
Spons merupakan biota laut multi sel yang fungsi jaringan dan organnya sangat sederhana. Spons memiliki potensi cukup besar dalam menghasilkan senyawa aktif yang dapat digunakan dalam dunia farmasi. Penelitian ini bertujuan untuk menentukan adanya Aktivitas Antimikroba dari ekstrak dan fraksi Spons Stylissa carteri terhadap mikroba Staphylococcus aureus, Escherichia coli, dan Candida albicans. Dilakukan proses ekstraksi dengan cara maserasi terhadap sampel menggunakan pelarut etanol, dan dilakukan fraksinasi menggunakan pelarut metanol, n-heksan dan kloroform. Aktivitas antimikroba dilakukan dengan metode difusi agar. Hasil penelitian menunjukkan bahwa ekstrak kasar dan fraksi metanol dari spons Stylissa carteri aktif menghambat pertumbuhan mikroba Staphylococcus aureus, Escherichia coli, dan Candida albicans.
\end{abstract}

Kata Kunci : Stylissa carteri, antimikroba, Staphylococcus aureus, Escherichia coli, Candida albicans. 


\section{PENDAHULUAN}

Indonesia sebagai negara yang sangat kaya dengan sumber daya alam yang melimpah dengan luas lautannya terdiri dari 5,8 juta $\mathrm{km}^{2}$ atau sekitar $70 \%$ dari luas total wilayah Indonesia. Wilayah lautan Indonesia terdapat berbagai macam spesies organsime laut baik tumbuhan maupun hewan. Salah satu invertebrata yang jumlahnya sangat banyak di lautan Indonesia ialah spons. Spons laut memiliki potensi bioaktif yang sangat besar. Selama 50 tahun terakhir telah banyak kandungan bioaktif yang ditemukan. Kandungan bioaktif tersebut dikelompokan kedalam kelompok yang besar seperti antiflammantory, antitumor, antivirus, antimalaria, antibiotik (Rasyid, 2009).

Senyawa antimikroba yang dihasilkan oleh mikroba pada umumnya merupakan metabolit sekunder yang tidak digunakan untuk proses pertumbuhan, tetapi digunakan untuk pertahanan diri dan persaingan dengan mikroba lain dalam mendapatkan nutrisi, habitat, oksigen dan cahaya. Antimikroba dapat digolongkan dalam antibakteri atau antifungi. Beberapa ekstrak yang didapatkan memiliki kemampuan dalam menghambat pertumbuhan mikroba. Ekstrak ialah sediaan yang diperoleh dengan mengekstraksi senyawa aktif dari simplisia nabati atau hewani menggunakan pelarut yang sesuai, kemudian semua atau hampir semua pelarut diuapkan (Ditjen POM, 2000).

Spons ialah salah satu hewan dari filum porifera juga merupakan invertebrata laut yang hidup pada ekosistem terumbu karang. Spons merupakan biota laut multi sel yang fungsi jaringan dan organnya sangat sederhana. Spons Stylissa carteri dapat menghasilkan metabolit sekunder dari proses metabolisme dalam sel yang ada pada tubuhnya. Adapun metabolit sekunder yang dihasilkan memiliki struktur yang khas dibandingkan spesies-spesies organisme laut lainnya, karena bergantung pada lingkungan dan interaksi (simbiosis) dengan organisme lainnya, baik pada organisme yang menguntungkan maupun predator. Dari berbagai penelitian, spesies ini memiliki senyawa metabolit sekunder berupa alkaloid, steroid, dan terpenoid (Gozcelioglu dan Konuklugil, 2012).

\section{METODOLOGI PENELITIAN Waktu dan Tempat Penelitian}

Penelitian ini dilaksanakan pada bulan September 2018 sampai bulan Desember 2018 di Laboratorium Farmasi Lanjutan, Laboratorium Farmakologi serta Laboratorium Mikrobiologi Program Studi Farmasi Fakultas Matematika dan Ilmu Pengetahuan Alam Universitas Sam Ratulangi.

\section{Bentuk Penelitian}

Bentuk penelitian ini ialah eksperimen laboratorium yang akan menguji komponen yang diekstrak dari Spons Stylissa carteri sebagai antimikroba yang diperoleh dari perairan Selat Lembeh.

\section{Alat dan Bahan}

\section{a. Alat}

Alat yang digunakan dalam penelitian ini yaitu masker, sarung tangan, gunting, pisau, tabung oksigen, snorkel, fins, zipper lock bag, botol $600 \mathrm{ml}$, talenan, cool box, kamera underwater, erlenmeyer (Pyrex), corong, oven, timbangan analitik, spatula, corong pisah, gelas ukur, gelas kimia (Pyrex), cawan petri, autoklaf, pinset, pembakar spritus, vortex mixer, micro tubes, batang pengaduk, Laminar air flow, rak tabung reaksi, tabung reaksi, lemari 
pendingin, inkubator, cakram (paper disc), mikropipet, digital caliper, kertas label, spidol permanen.

b. Bahan

Bahan-bahan yang digunakan yaitu Spons Stylissa carteri, mikroba uji Staphylococcus aureus, Escherichia coli, dan Candida albicans, etanol 96\%, akuades, metanol, n-heksan, kloroform, nutrient broth, nutrien agar, potato dextrose agar, kloramfenikol, kertas cakram, label, spidol permanen, tissue, aluminium foil, kertas saring, kapas.

\section{Prosedur Penelitian}

\section{Ekstraksi}

Spons Stylissa carteri., sebanyak 288 g diekstraksi dengan menggunakan cara maserasi. Sampel dipotong kecil-kecil dengan ukuran $1 \mathrm{~cm}^{2}$ lalu dimasukkan ke dalam botol dan direndam dengan larutan etanol 96\% sampai sampel terendam secara keseluruhan dan dibiarkan selama 24 jam. Sampel yang direndam disaring dengan menggunakan kertas saring menghasilkan filtrat 1 dan debris 1 . Debris 1 direndam dengan larutan etanol $96 \%$ sampai sampel terendam secara keseluruhan kemudian dibiarkan selama 24 jam. Sampel tersebut disaring menggunakan kertas saring menghasilkan filtrat 2 dan debris 2. Debris 2 kemudian direndam dalam larutan etanol 96\% sampai sampel terendam secara keseluruhan dan dibiarkan selama 24 jam, sampel tersebut disaring menggunakan kertas saring menghasilkan filtrat 3 dan debris 3 . Filtrat 1, 2 dan 3 dicampur menjadi satu kemudian disaring, lalu dievaporasi menggunakan rotary evaporator sehingga didapat ekstrak kasar Spons Stylissa carteri., kemudian ditimbang menggunakan timbangan analitik, diperoleh ekstrak etanol sebanyak 2,64 g. Selanjutnya ekstrak etanol
Spons Stylissa carteri digunakan dalam fraksinasi dan pengujian antimikroba.

\section{Fraksinasi}

Sebanyak 1,00 g ekstrak etanol Spons Stylissa carteri dimasukkan ke dalam Erlenmeyer dan dilarutkan dengan 100ml metanol $80 \%$. Setelah sampel larut, sampel dimasukkan ke dalam corong pisah dan ditambahkan pelarut n-heksan sebanyak 100 $\mathrm{mL}$. Sampel kemudian dikocok berulangkali dalam corong pisah hingga homogen. Sample dibiarkan hingga membentuk lapisan metanol $(\mathrm{MeOH})$ dan lapisan n-heksan. Masingmasing lapisan metanol dan lapisan n-heksan ditampung di dalam wadah yang berbeda. Lapisan n-heksan selanjutnya dievaporasi menggunakan rotary evaporator hingga kering, lalu ditimbang dengan timbangan analitik dan diperoleh fraksi n-heksan sebanyak $1,75 \mathrm{~g}$. Selanjutnya lapisan metanol ditambahkan dengan akuades $100 \mathrm{~mL}$, kemudian dipartisi dengan pelarut kloroform menggunakan perbandingan $1: 1 \mathrm{v} / \mathrm{v}$ setelah itu dikocok dalam corong pisah hingga homogen. Lapisan metanol dibiarkan hingga membentuk dua lapisan yaitu lapisan metanol dan lapisan kloroform. Masing-masing lapisan metanol dan lapisan kloroform ditampung ke dalam wadah yang berbeda. Lapisan kloroform dievaporasi menggunakan rotary evaporator hingga kering lalu ditimbang dengan timbangan analitik dan diperoleh fraksi kloroform sebanyak 1,484 g. Lapisan metanol yang ditampung pada wadah lain dievaporasi menggunakan rotary evaporator hingga kering lalu ditimbang dengan timbangan analitik dan diperoleh fraksi metanol sebanyak 7,4 g. Ketiga fraksi yang diperoleh akan digunakan dalam pengujian antimikroba. Rendemen-rendemen ekstrak dan fraksi dihitung dengan persamaan berat hasil ekstrak/fraksi 
dibagikan dengan berat awal ekstrak/fraksi kemudian dikalikan dengan $100 \%$.

\section{Sterilisasi dan Pembuatan Media Sterilisasi Alat}

Alat-alat gelas yang digunakan dalam penelitian aktivitas antimikroba ini disterilkan terlebih dahulu dengan menggunakan autoklaf pada suhu $121{ }^{\circ} \mathrm{C}$ selama 15 menit, pinset dibakar dengan pembakaran di atas api langsung dan media disterilkan di autoklaf pada suhu $121{ }^{\circ} \mathrm{C}$ selama 15 menit (Ortez, 2005).

\section{Pembuatan Media Cair BI}

Pepton 0,5 g, beef extract 0,3 g, natrium klorida $0,3 \mathrm{~g}$ dan akuades sebanyak $100 \mathrm{ml}$ diaduk sampai homogen kemudian disterilkan dalam autoklaf pada suhu $121^{\circ} \mathrm{C}$ selama 15 menit dan setelah itu didinginkan. Setelah dingin, media cair B1 di tutup dengan aluminium foil (Dwijendra et al, 2014).

\section{Pembuatan Media Uji}

Pepton 0,5 g, beef extract 0,3 g, natrium klorida $0,3 \mathrm{~g}$, agar $1,5 \mathrm{~g}$ dan akuades sebanyak $100 \mathrm{ml}$ diaduk sampai homogen kemudian disterilkan di autoklaf pada suhu $121^{\circ} \mathrm{C}$ selama 15 menit (Dwijendra et al., 2014).

\section{Pembuatan Larutan Uji}

Larutan uji dibuat dengan cara $1 \mathrm{mg}$ ekstrak kasar Spons Stylissa carteri. dilarutkan dalam $200 \mu \mathrm{L}$ metanol dan dikocok hingga homogen menggunakan vortex. Perlakuan yang sama dilakukan pada fraksi n-heksan, fraksi kloroform dan fraksi metanol (Ortez, 2005).

\section{Pembuatan Kontrol Positif dan Kontrol Negatif}

Kontrol positif dalam pengujian aktivitas antimikroba ini menggunakan kloramfenikol paper disc. Kontrol negatif yang digunakan dalam penelitian ini yaitu menggunakan pelarut metanol, dengan cara membuat larutan stok metanol dengan mengambil sebanyak $200 \mu \mathrm{L}$ metanol kemudian di totolkan pada paper disc (Lalamentik, 2017).

\section{Pengujian Aktivitas Antimikroba}

Metode yang digunakan dalam penelitian ini yaitu metode difusi agar (disc diffusion Kirby and Bauer). Pada pengujian aktivitas antimikroba ini, cakram (paper disc) yang digunakan berukuran $6 \mathrm{~mm}$ dengan daya serap $50 \mu \mathrm{L}$ tiap cakram. Sebanyak $300 \mu \mathrm{L}$ mikroba yang telah dikultur, dipipet dan diinokulasi pada $30 \mathrm{ml}$ media agar lalu diaduk hingga homogen dan kemudian dituangkan ke dalam cawan petri dan tunggu sampai media agar mengeras. Kemudian, larutan uji yang telah disiapkan ditotolkan pada masing-masing cakram dengan menggunakan mikropipet. Setelah agar mengeras, kertas cakram yang telah ditotolkan sampel Spons Stylissa carteri, kontrol positif dan kontrol negatif diletakkan ke dalam cawan petri dengan menggunakan pinset. Selanjutnya, cawan petri diberi label dan diinkubasi dalam inkubator pada suhu $37^{\circ} \mathrm{C}$ selama 1 x 24 Jam (Ortez, 2005).

\section{Pengamatan dan Pengukuran Diameter Zona Hambat}

Pengamatan dilakukan setelah 24 jam masa inkubasi. Daerah pada sekitar cakram menunjukkan kepekaan mikroba terhadap antibiotik atau bahan antimikroba yang digunakan sebagai bahan uji yang dinyatakan 
dengan diameter zona bening. Diameter zona bening diukur menggunakkan digital caliper. Kemudian zona bening yang telah diukur, dikategorikan berdasarkan pedoman Davis dan Stout (1971).

\section{Hasil dan Pembahasan \\ Ekstraksi dan Fraksinasi}

Spons Stylissa carteri yang telah diambil dari Selat Lembeh Bitung dipotong kecil-kecil dengan ukuran $\pm 1 \mathrm{~cm}^{2}$. Hal ini bertujuan untuk memperbesar ukuran permukaan sampel sehingga proses ekstraksi dapat berjalan optimal karena semakin luas permukaan sampel maka interaksi antara pelarut dan sampel semakin baik. Sampel kemudian di ekstraksi dengan menggunakan metode maserasi.

Penggunaan metode maserasi paling mengguntungkan pada isolasi senyawa bahan alam laut, karena pada saat perendaman sampel akan terjadi pemecahan dinding sel dan membrane sel pada sampel, karena terdapat perbedaan tekanan didalam dan diluar sel sehingga metabolit sekunder akan terlarut dalam pelarut organik dan ekstrak senyawa yang dihasilkan akan sempurna karena mudah diatur melalui proses perendaman. Sampel spons Stylissa carteri dilakukan dengan etanol $96 \%$ sampai semuai sampel terendam, karena pelarut etanol $96 \%$ memiliki sifat selektif, tidak beracun dan bersifar universal yang cocok untuk mengekstrak semua golongan senyawa metabolit sekunder (Kristianti et al., 2008). Metode maserasi dipilih karena cara kerja dan peralatan yang digunakan sederhana, mudah diusahakan, mampu menarik senyawa-senyawa yang berkhasiat, dan untuk menghindari kerusakan beberapa senyawa aktif dari Spons Stylissa carteri (Kristiani, 2014).
Tabel 1. Rendemen ekstrak Spons Stylissa carteri

\begin{tabular}{ccccc}
\hline No. Sampel & $\begin{array}{c}\text { Massa } \\
\text { Ekstrak } \\
(\mathrm{g})\end{array}$ & $\begin{array}{c}\text { Rendemen } \\
(\%)\end{array}$ & $\begin{array}{c}\text { Warna } \\
\text { Sampel }\end{array}$ \\
\hline 1. & $\begin{array}{c}\text { Ektsrak } \\
\text { Etanol }\end{array}$ & 7,4 & 740 & $\begin{array}{c}\text { Orange } \\
\text { pekat }\end{array}$ \\
\hline
\end{tabular}

Setelah dilakukan proses maserasi selanjutnya dilakukan proses fraksinasi dimana metode penelitian ini menggunakan metode fraksinasi cair-cair, yang merupakan metode pemisahan dengan menggunakan dua pelarut dalam satu corong pisah sehingga senyawa tidak saling tercampur karena memiliki sifat kepolaran yang berbeda. Pelarut yang digunakan untuk proses fraksinasi ini yaitu n-heksan, kloroform dan metanol. Proses fraksinasi dilakukan secara bertingkat berdasarkan tingkat kepolaran pelarut yaitu mulai dari pelarut non polar selanjutnya semi polar dan terakhir pelarut polar (Engka, 2016).

Table 2. Massa fraksi beserta rendemen

\begin{tabular}{|c|c|c|c|c|}
\hline No. & Sampel & $\begin{array}{c}\text { Massa } \\
\text { Ekstrak } \\
\text { (g) }\end{array}$ & $\begin{array}{c}\text { Rendemen } \\
(\%)\end{array}$ & $\begin{array}{l}\text { Warna } \\
\text { Sampel }\end{array}$ \\
\hline 1. & $\begin{array}{l}\text { Fraksi } \\
\text { Heksan }\end{array}$ & 1,75 & 175 & $\begin{array}{l}\text { Kuning } \\
\text { jernih }\end{array}$ \\
\hline 2. & $\begin{array}{c}\text { Fraksi } \\
\text { Kloroform }\end{array}$ & 1.484 & 148 & $\begin{array}{l}\text { Kuning } \\
\text { keruh }\end{array}$ \\
\hline 3. & $\begin{array}{c}\text { Fraksi } \\
\text { Metanol }\end{array}$ & 7,4 & 740 & $\begin{array}{c}\text { Kuning } \\
\text { kecokelatan }\end{array}$ \\
\hline
\end{tabular}

Perbedaan nilai rendemen ini disebabkan oleh perbedaan jenis pelarut yang digunakan. Pelarut yang berbeda akan melarutkan senyawa-senyawa yang berbeda tergantung tingkat kepolarannya. Oleh sebab itu, jumlah ekstrak yang dihasilkan tergantung jenis pelarutnya (Mujipradhana et al., 2018).

Jumlah rendemen ekstrak bergantung pada kondisi alamiah senyawa, metode 
ekstraksi, ukuran partikel sampel, dan waktu ekstraksi, serta perbandingan sampel dengan pelarut (Harborne, 1987).

\section{Uji Aktivitas Antimikroba Spons Stylissa carteri}

Pengujian aktivitas antimikroba dengan menggunakan mikorba uji Staphylococcus aureus, Escherichia coli, dan Candida albicans dari ekstrak etanol, fraksi metanol, fraksi n-heksan dan farksi kloroform menggunakan metode difusi agar. Metode difusi agar adalah metode yang dilakukan dengan pengukuran dan pengamatan diameter zona bening yang terbentuk disekitar cakram yang berisi zat antimikroba yang diletakkan pada media agar yang telah diinokulasi mikroba (Lalamentik, 2017). Mikroba uji yang digunakan adalah Staphylococcus aureus untuk mewakili bakteri Gram positif, Escherichia coli untuk mewakili bakteri Gram negatif dan Candida albicans untuk mewakili jamur. Tujuan penggunaan mikroba ini untuk mengetahui apakah ekstrak dan fraksi dari Stylissa carteri memiliki aktivitas antimikroba serta untuk mengetahui spektrum aktivitas antimikroba dari Stylissa carteri apakah memiliki spektrum luas, yaitu dapat membunuh banyak jenis mikroba seperti bakteri Gram positif dan Gram negatif, atau spektrum sempit yaitu hanya membunuh salah satu dari bakteri Gram positif atau bakteri Gram negatif.

Hasil yang didapatkan pada pengujian ini, yaitu adanya zona hambat disekeliling cakram yang berukuran $6 \mathrm{~mm}$ (paper disc) ditandai dengan adanya zona bening, hal ini menunjukkan adanya kepekaan mikroba terhadap ekstrak atau fraksi dari spons Stylissa carteri dan antibiotik yang digunakan sebagai kontrol positif. Dilakukan pengamatan setelah di inkubasi pada suhu $37^{\circ} \mathrm{C}$ selama $1 \times 24 \mathrm{jam}$ dengan $3 \mathrm{kali}$ pengulangan pada masing-masing mikroba, pengulangan dilakukan untuk lebih mengakuratkan hasil yang akan diperoleh (Mujipradana et al., 2018)

Tabel 3. Hasil rata-rata Aktivitas Antimikroba

\begin{tabular}{cccccccc}
\hline & \multicolumn{6}{c}{ Rata- Rata Diameter (mm) } \\
\cline { 2 - 7 } Mikroba & EE & FH & FK & FM & + & - \\
\hline Ec & I & 9,00 & 0,00 & 0,00 & 13,00 & 18,00 & 0,00 \\
& II & 9,00 & 0,00 & 0,00 & 13,00 & 18,00 & 0,00 \\
& III & 8,00 & 0,00 & 0,00 & 13,00 & 18,00 & 0,00 \\
& $\mathbf{\Sigma}$ & 26,00 & 0,00 & 0,00 & 38,00 & 54,00 & 0,00 \\
& $\bar{X}$ & 8,66 & 0,00 & 0,00 & 12,66 & 18,00 & 0,00 \\
& & & & & & & \\
Sa & I & 8,14 & 0,00 & 0,00 & 13,76 & 18,46 & 0,00 \\
& II & 8,14 & 0,00 & 0,00 & 13,76 & 18,46 & 0,00 \\
& III & 8,14 & 0,00 & 0,00 & 13,76 & 18,46 & 0,00 \\
& $\mathbf{\Sigma}$ & 24,42 & 0,00 & 0,00 & 41,28 & 55,38 & 0,00 \\
& $\bar{X}$ & 8,14 & 0,00 & 0,00 & 13,76 & 18,46 & 0,00 \\
& & & & & & & \\
Ca & I & 12,00 & 0,00 & 0,00 & 11,00 & 20,00 & 0,00 \\
II & 12,00 & 0,00 & 0,00 & 11,00 & 20,00 & 0,00 \\
& III & 12,00 & 0,00 & 0,00 & 11,00 & 20,00 & 0,00 \\
& $\mathbf{\Sigma}$ & 36,00 & 0,00 & 0,00 & 33,00 & 60,00 & 0,00 \\
& $\bar{X}$ & 12,00 & 0,00 & 0,00 & 11,00 & 20,00 & 0,00 \\
& & & & & & \\
\hline
\end{tabular}

Keterangan :

(Sa) Staphylococcus aureus

(Ec) Eschericia coli

(Ca) Candida Albicans

(EE) Ekstrak Etanol

(FH) Fraksi Heksan

(FK) Fraksi Kloroform

(FM) Fraksi Metanol

( $\Sigma$ Jumlah zona bening

$(\bar{X}) \quad$ Jumlagh Rata-rata

Digunakan kontrol positif dan negatif sebagai pembanding. Kontrol positif yang digunakan dalam penelitian ini yaitu 
kloramfenikol, digunakan kloramfenikol sebagai kontrol positif dikarenakan kloramfenikol memiliki spektrum yang luas. Penggunaan kontrol positif berfungsi sebagai kontrol dari zat uji, dengan membandingkan diameter daerah hambat yang terbentuk (Dwijendra et al., 2014). Diperoleh zona hambat dari kontrol positif kloramfenikol yaitu sebesar 20,00 mm dibandingkan dengan ekstrak dan fraksi dari Stylissa carteri.

Kontrol negatif yang digunakan yaitu metanol. Kontrol negatif digunakan untuk mengetahui ada atau tidaknya pengaruh terhadap pertumbuhan mikroba uji, sehingga dapat diketahui bahwa aktivitas yang ditunjukan oleh ekstrak atau fraksi ialah zat yang terkandung dalam sampel bukan berasal dari pelarut yang digunakan.

Pada penelitian ini ekstrak etanol dan fraksi metanol merupakan ekstrak dan fraksi yang efektif dalam menghambat pertumbuhan bakteri gram positif Staphylococcus aureus bakteri gram negatif Escherichia coli dan jamur Candida albicans. Terdapat respon yang berbeda dari dua golongan bakteri dan jamur terhadap senyawa antimikroba. Hal ini disebabkan karena adanya perbedaan kepekaan pada bakteri Gram positif, bakteri Gram negatif dan jamur terhadap senyawa antimikroba yang terkandung dalam ekstrak dan fraksi Spons Stylissa carteri. Bakteri Gram positif cenderung lebih sensitif terhadap komponen antimikroba. Hal ini disebabkan oleh struktur dinding sel bakteri Gram positif lebih sederhana sehingga memudahkan senyawa antimikroba untuk masuk ke dalam sel dan menemukan sasaran untuk bekerja, sedangkan struktur dinding sel bakteri Gram negatif lebih kompleks dan berlapis tiga, yaitu lapisan luar berupa lipoprotein, lapisan tengah yang berupa peptidoglikan, dan lapisan dalam lipopolisakarida (Pelczar dan Chan, 1986).

Pada pengujian aktivitas antimikroba dari sampel Spons Stylissa carteri penggolangan kekuatan daya antimikroba digolongkan menurut pedoman Davis and Stout (1971) yang ditunjukkan pada Tabel 4.

Tabel 4. Kategori Kekuatan Daya Antimikroba

\begin{tabular}{cc}
\hline $\begin{array}{c}\text { Diameter Zona } \\
\text { Bening(mm) }\end{array}$ & Kategori \\
\hline$\geq 20$ & Sangat Kuat \\
$10-20$ & Kuat \\
$5-10$ & Sedang \\
$\leq 5$ & Lemah \\
\hline
\end{tabular}

Pada ekstrak etanol menunjukkan bahwa zona bening yang terbentuk pada Escherichia coli tergolong sedang yaitu $(9,00 \mathrm{~mm})$ dan pada Staphylococcus aureus juga tergolong sedang yaitu $(8,14 \mathrm{~mm})$ sedangkan pada Candida albicans zona bening yang terbentuk tergolong besar yaitu $(11,00 \mathrm{~mm})$. Hal ini menunjukkan bahwa ekstrak etanol memiliki spektrum kerja yang luas dalam menghambat aktivitas antimikroba dengan bakteri Staphylococcus aureus, Escherichia coli dan jamur Candida albicans.

Pada fraksi kloroform menunjukkan bahwa tidak terdapat zona bening yang terbentuk pada Escherichia coli yaitu $(0,00 \mathrm{~mm})$ dan pada Staphylococcus aureus juga tidak terdpat zona bening yaitu $(0,00 \mathrm{~mm})$ begitupun pada Candida albicans tidak terdapat zona bening yang terbentuk yaitu $(00,00 \mathrm{~mm})$.

Hal ini menunjukkan bahwa fraksi kloroform memiliki spektrum kerja yang sempit dalam menghambat aktivitas antimikroba dengan bakteri Staphylococcus aureus, Escherichia coli dan jamur Candida albicans. 
Pada fraksi metanol menunjukkan bahwa zona bening yang terbentuk pada Escherichia coli tergolong kuat yaitu $(13,00 \mathrm{~mm})$ dan pada Staphylococcus aureus juga tergolong kuat yaitu $(13,76 \mathrm{~mm})$ sedangkan pada Candida albicans zona bening yang terbentuk tergolong besar yaitu $(12,00 \mathrm{~mm})$. Hal ini menunjukkan bahwa fraksi metanol memiliki spektrum kerja yang luas dalam menghambat aktivitas antimikroba dengan bakteri Staphylococcus aureus, Escherichia coli dan jamur Candida albicans.

Pada fraksi $\mathrm{n}$-heksan menunjukkan bahwa tidak terdapat zona bening yang terbentuk pada Escherichia coli yaitu $(0,00 \mathrm{~mm})$ dan pada Staphylococcus aureus juga tidak terdpat zona bening yaitu (0,00mm) begitupun pada Candida albicans tidak terdapat zona bening yang terbentuk yaitu $(00,00 \mathrm{~mm})$. Hal ini menunjukkan bahwa fraksi n-heksan memiliki spektrum kerja yang sempit dalam menghambat aktivitas antimikroba dengan bakteri Staphylococcus aureus, Escherichia coli dan jamur Candida albicans.

Dari hasil yang diperoleh menunjukkan bahwa ekstrak etanol dan fraksi metanol menghasilkan zona bening berdiameter sedang dan besar yang mampu mengambat pertumbuhan mikroba uji Staphylococcus aureus, Escherichia coli dan Candida albicans. Sedangkan untuk fraksi kloroform dan n.heksan tidak adanya kepekaan aktivitas antimikroba umtuk itu tidak terdapat zona bening pada saat pengujian.

\section{KESIMPULAN}

Berdasarkan hasil penelitian yang telah dilakukan dapat disimpulkan bahwa spons Stylissa carteri yang diperoleh dari Selat Lembeh Bitung hanya memiliki aktivitas antimikroba pada ekstrak etanol dan fraksi metanol. Aktivitas yang dihasilkan dari bakteri Staphylococcus aureus, Escherichia coli dan Candida albicans tergolong aktivitas yang sedang $8.14 \mathrm{~mm}$ dan besar $13,76 \mathrm{~mm}$. Sedangkan untuk fraksi kloroform dan n-heksan tidak adanya kepekaan aktivitas antimikroba untuk itu tidak terdapat zona bening pada saat pengujian.

\section{SARAN}

Berdasarkan hasil dan pembahasan aktivitas antimikroba ekstrak dan fraksi spons Stylissa carteri, maka dapat disarankan perlu dilakukan penelitian lebih lanjut tentang uji antimikroba dengan metode pengujian yang berbeda atau dengan menggunakan mikroba uji yang berbeda.

\section{DAFTAR PUSTAKA}

Davis, W. W., T.R. Stout. 1971. Disc plate method of microbiological assay. Journal of microbiology. 22: 659-665.

Ditjen POM. 2000. Parameter Standar Umum Ekstrak Tumbuhan Obat. Cetakan Pertama. Jakarta: Departeman Kesehatan RI. Hal : 1012.

Dwijendra, I. M., D. S. Wewengkang., F. Wehantou. 2014. Aktivitas Antibakteri dan Karakterisasi Senyawa Fraksi Spons Lamellodysidea herbacea yang diperoleh dari Teluk Manado. Pharmacon. 3(4): 1-9.

Engka, T. 2016. Aktivitas Antioksidan dan Penentuan Kandungan Total Fenolik dan Flavonoid dari Umbi Kuso Mafola (Drynaria quercifolia L.) 
[skripsi]. $\quad$ Program Studi

Farmasi FMIPA

Universitas Sam Ratulangi, Manado.

Gozcelioğlu, B., Konuklugil, B., 2012, Qualitative Detection of Some Secondary Metabolites from Three Turkish Marine Sponges, Fabad J. Pharm. Sci., 37: 73-78.

Harborne,J.B. 1987. Metode Fitokimia: Penentuan cara modern menganalisis tumbuhan. Kokasih Padmawita, Iwang Soediro. Penerjemah. Bandung: ITB. Terjemahan dari: Phytochemical methods.

Huliselan, Y. M.,M.R.J. Runtuwene., D.S.Wewengkang. 2015. Aktivitas Antioksidan Ekstrak Etanol, Etil Asetat dan N-Heksan dari Daun Sesewanua (Clerodendron squamatum Vahl). Pharmacon.4(3): 155-163.

Kristiani, V 2014. Pengaruh Konsentrasi etanol dan Waktu Maserasi Terhadap Perolehan Fenolik, Flavonoid, dan Aktivitas Antioksidan Ekstrak Rmbut Jagung [skripsi]. Fakultas Teknik universitas Katolik Widya Mandala, Surabaya.

Kristanti, A. N., N.S. Aminah., M. Tanjung., B. Kurniadi. 2008. Buku Ajar Fitokimia. Unair Press, Surabaya.

Mujipradana, V.N., D. S. Wewengkang., E. Suryanto. 2018. Aktivitas Antimikroba dari Ekstrak Ascidian Herdmania momus pada Mikroba Patogen Manusia. Pharmacon. 7(3): 338-347.

Ortez, J. H. 2005. Disk Diffusion testing in manual of antimicrobial susceptibility testing. Marie $B$.
Coyle (Coord. Ed). American society for Microbiology, America.

Pelczar, M. J., Chan, E. C. S., 1986. Dasardasar Mikrobiologi. Terjemahan Hadioetomo, R.S. Imas, T.S.S., Tjitrosomo. Jakarta : UI Press.

Rasyid A. 2009. Senyawa-senyawa Bioaktif dari Spons. Oseana. Hlm 25-32. Schlagel.G.H. 1993.General Microbiologi seventh eition. Cambrige University Press. 